\title{
Inhibition of GSK-3ß enhances reovirus-induced apoptosis in colon cancer cells
}

\author{
HYE-JIN MIN ${ }^{1}$, SANG SEOK KOH ${ }^{2}$, IL-RAE CHO ${ }^{1}$, RATAKORN SRISUTTEE ${ }^{1}$, \\ EUN-HEE PARK ${ }^{1}$, BYUNG HAK JHUN ${ }^{1}$, YONG-GYUN KIM ${ }^{3}$, SANGTAEK OH ${ }^{4}$, \\ JU EUN KWAK $^{5}$, RANDAL N. JOHNSTON ${ }^{6}$ and YOUNG-HWA CHUNG ${ }^{1}$ \\ ${ }^{1}$ Department of Nanomedical Engineering, BK21 Nanofusion Technology Team,
} Pusan National University, Miryang, Gyeongnam 627-706; ${ }^{2}$ Therapeutic Antibody Research Center, Korea Research Institute of Bioscience and Biotechnology, Daejeon 305-333; ${ }^{3}$ Department of Life Science and Environmental Chemistry, Pusan National University, Miryang, Gyeongnam 627-706; ${ }^{4}$ Pharmaco Genomics Research Center, Inje University, Busan 614-735; ${ }^{5}$ Department of Life Science, Pohang University of Science and Technology, Pohang 790-784, Korea; ${ }^{6}$ Department of Biochemistry and Molecular Biology, University of Calgary, Calgary, Alberta T2N 4N1, Canada

Received January 27, 2009; Accepted March 30, 2009

DOI: 10.3892/ijo_00000373

\begin{abstract}
Reovirus functions as an oncolytic agent for many types of cancer including colon cancer. Although most studies have emphasized the role of activated Ras signaling in enhancing reoviral oncolysis in susceptible cells, we note that many colon cancers also display elevated $\beta$-catenin. Thus, it is possible that enhanced $\beta$-catenin may augment reoviral susceptibility in colon cancer cells. To explore this hypothesis, HEK293 cells were treated with the glycogen synthase kinase (GSK)-3ß inhibitor $\mathrm{LiCl}$, thereby inducing $\beta$-catenin, followed by reoviral infection. Co-administration with $\mathrm{LiCl}$ indeed enhanced cell death compared to reovirus infection alone, but this was not associated with elevated reoviral replication. Similarly, HEK293 cells expressing the Frizzled-1 receptor in Wnt3a-conditioned medium also showed reovirus replication equivalent to that in cells in control medium, further suggesting that up-regulation of $ß$-catenin does not enhance the replication of reovirus. Instead, we observed that inhibition of GSK-3ß with $\mathrm{LiCl}$ decreased reovirus-induced $\mathrm{NF}-\kappa \mathrm{B}$ activation, leading to accelerated apoptosis via
\end{abstract}

Correspondence to: Dr Young-Hwa Chung, Department of Nanomedical Engineering, BK21 Nanofusion Technology Team, Pusan National University, Miryang, Gyeongnam 627-706, Korea E-mail: younghc@pusan.ac.kr

Abbreviations: GSK, glycogen synthase kinase; NF-кB, nuclear factor-кB; HEK, human embryonic kidney; LiCl, lithium chloride; JNK, c-Jun N-terminal kinase; MAPK, mitogen-activated protein kinase

Key words: reovirus, glycogen synthase kinase-3ß, ß-catenin, nuclear factor- $\mathrm{\kappa B}$, colon cancer caspase 8 activation. We further found that colon cancer HCT116 cells were sensitized to apoptosis by co-treatment with reovirus and a GSK-3ß inhibitor, AR-A014418. Finally, we identified that inhibition of NF- $\mathrm{BB}$ sensitized apoptosis of HEK293 or HCT 116 cells during reovirus infection. Taken together, we propose that inhibition of GSK-3ß sensitizes reovirus-induced apoptosis of colon cancer cells by downregulation of NF- $\mathrm{KB}$ activity, offering a potentially improved therapeutic strategy for the treatment of colon cancer.

\section{Introduction}

The human reovirus is a ubiquitous, non-enveloped virus with 10 segments of double-stranded RNA (1). Virus infection is usually restricted to the upper respiratory and gastrointestinal tracts and is often asymptomatic or causing mild disease $(2,3)$. However, reovirus also displays striking cytolytic activity in certain types of transformed cells $(4,5)$. Evidence that Ras-transformed cells are preferentially susceptible to reovirus T3D (type 3 Dearling strain) via inactivation of the protective PKR (dsRNA-activated protein kinase) phosphorylation pathway has been reported (6-8) although our study has revealed that Ras activation alone does not enable reovirus to induce oncolysis in hepatocellular cacinoma cells expressing HBX, an oncoprotein of hepatitis B virus (9). Furthermore, the use of reovirus in the treatment of gliomas in immunocompetent hosts and the inoculation of reovirus into the brains of non-human primates have not produced significant toxicities (10), thereby supporting the current tests of reovirus in several clinical trials (11).

On the other hand, it has been reported that reoviral oncolysis is associated with the induction of apoptosis in various types of cancer (12-14). Further investigation has revealed that TNF-related apoptosis-inducing ligand (TRAIL), a member of the TNF superfamily is involved in reovirusinduced apoptosis (15). Caspase 8 and JNK MAPK molecules 
also participate in apoptotic signaling following reoviral infection $(16,17)$.

Glycogen synthase kinase-3 (GSK-3) is a ubiquitously expressed serine/threonine kinase that regulates glycogen synthesis (18). GSK-3 has 2 isoforms (GSK-3 $\alpha$ and GSK-3ß) which are highly homologous but exhibit different substrate specificities in vitro (19). GSK-3 $\alpha$ and GSK-3ß have been implicated in cell-fate determination and differentiation in a variety of organisms (20). In particular, GSK-3B functions as a member in complexes of the adenomatous polyposis coli (APC), Axin, and B-catenin. In this model, GSK-3ß can directly phosphorylate $B$-catenin and target it for degradation via ubiquitin-mediated proteosomes (21). Thus, GSK-3ß participates as part of a tumor suppressor complex that regulates the levels of the oncoproteins, B-catenin (22). Consistent with this, disruption of the murine GSK-3ß gene results in embryonic lethality, and mouse embryonic fibroblasts (MEFs) derived from these animals are more sensitive to apoptosis (23). Further studies have revealed that GSK-3ßknockout MEFs harbor an intrinsic defect in the activation of $\mathrm{NF}-\kappa \mathrm{B}$ during TNF- $\alpha$ signaling (23), raising the possibility that GSK-3ß indeed contributes to cell survival at least in part through the involvement of NF- $\mathrm{KB}$ signaling.

To examine whether the up-regulation of $\beta$-catenin which is frequently noted in colon cancer cells might enable the preferential replication of reovirus in a manner similar to that following Ras activation, we initiated the present study. Here, we report that inhibition of GSK-3B can indeed enhance reovirus-induced apoptosis of the cell, by down-regulation of $\mathrm{NF}-\kappa \mathrm{B}$ activity and irrespective of up-regulation of $\beta$-catenin. This raises the possibility that the combined administration of a GSK inhibitor together with reovirus could be an efficient regimen for the treatment of colon cancer cells.

\section{Materials and methods}

Cell cultures and virus amplification. Human embryonic kidney (HEK)293, HEK293 stably expressing Frizzle-1 (HEK293-Fz), murine L929, and colon cancer HCT116 cells were cultured in DMEM supplemented with $10 \%$ FBS and $1 \%$ penicillin and streptomycin. The Dearing strain of reovirus serotype 3 purchased from the ATCC (Manassas, VA) was propagated in L929 cells. The virus was purified as described elsewhere $(24,25)$, and titer of virus was measured as plaque forming units (PFU).

Reagents and antibodies. To inhibit GSK-3ß activity, LiCl and AR-A014418 were purchased from Calbiochem (San Diego, CA), and Bay 11-7082 was obtained from Calbiochem to inhibit NF-кB activity. For immunoblotting, anti-caspase 3, caspase 8, PARP, and B-tubulin antibodies were obtained from Santa Cruz Biotech (Santa Cruz, CA). Anti-phosphoGSK-3ß (Ser9) and GSK-3ß antibodies were purchased from Cell Signaling Technology (Danvers, MA). Polyclonal antireovirus antibodies described previously (1) were used for the detection of $\lambda, \mu$ and $\sigma$ reoviral proteins.

Preparation of nuclear extract. Nuclear extracts were prepared according to a modified method described elsewhere (26). Cells were washed and harvested with ice-cold PBS, and the cell pellets were lysed with $500 \mu 1$ of buffer A [10 mM HEPES (pH 7.9), $1.5 \mathrm{mM} \mathrm{MgCl} 2,10 \mathrm{mM} \mathrm{KCl}, 1 \mathrm{mM}$ EDTA, $1 \mathrm{mM}$ DTT, $0.1 \%$ Triton X-100, $10 \%$ glycerol, $0.5 \mathrm{mM}$ PMSF and $1 \mathrm{X}$ cocktail protease inhibitor] on ice for $20 \mathrm{~min}$, followed by centrifugation at $10,000 \mathrm{x} \mathrm{g}$ for $15 \mathrm{~min}$. The supernatant was taken as a cytosol fraction, and the pellets were washed with $500 \mu 1$ of buffer $\mathrm{A}$, and the remaining pellets were subsequently solubilized in $500 \mu \mathrm{l}$ of buffer $\mathrm{C}$ [20 mM HEPES (pH 7.9), $450 \mathrm{mM} \mathrm{NaCl}, 1.5 \mathrm{mM} \mathrm{MgCl}_{2}$, $1 \mathrm{mM}$ EDTA, $1 \mathrm{mM}$ DTT, $10 \%$ glycerol, $0.5 \mathrm{mM}$ PMSF and $1 \mathrm{X}$ cocktail protease inhibitor] on ice for $30 \mathrm{~min}$. Extracts were centrifuged at $12,000 \times \mathrm{g}$ for $15 \mathrm{~min}$, and the supernatant was taken as a nuclear fraction.

Western blot assay. Cells were harvested and lysed with lysis buffer [150 mM NaCl, $1 \%$ NP-40, $50 \mathrm{mM}$ Tris- $\mathrm{HCl}(\mathrm{pH} 7.5)$ ] containing $0.1 \mathrm{mM} \mathrm{Na} \mathrm{VO}_{3}, 1 \mathrm{mM} \mathrm{NaF}$ and protease inhibitors (Sigma, St. Louis, MO). For immunoblotting, proteins from whole cell lysates were resolved by 10 or $12 \%$ SDS-PAGE and then transferred to nitrocellulose membranes. Primary antibodies were used at 1:1,000 or 1:2,000 dilutions, and secondary antibodies conjugated with horseradish peroxidase were used at 1:2,000 dilutions in 5\% nonfat dry milk. After a final washing, nitrocellulose membranes were exposed for an enhanced chemiluminescence assay using the LAS 3000 (Fuji, Japan).

Nuclear NF-кB pull-down assay. Using oligonucleotide conjugated with agarose, NF- $\mathrm{KB}$ transcription factor was isolated as described elsewhere (27). Nuclear extracts from cells treated with $\mathrm{LiCl}$, reovirus, or reovirus and $\mathrm{LiCl}$ were prepared as described above. In accordance with the manufacturer's instructions, NF- $\kappa \mathrm{B}$ consensus oligonucleotide-agarose conjugate (100 $\mu \mathrm{g}$; Santa Cruz) was incubated with $500 \mu \mathrm{g}$ of nuclear extracts in binding buffer $[10 \mathrm{mM}$ Tris (pH 7.5), $50 \mathrm{mM} \mathrm{NaCl}, 1 \mathrm{mM}$ DTT, $1 \mathrm{mM}$ EDTA, 5\% glycerol, $50 \mu \mathrm{g} / \mathrm{ml}$ poly(dI-dC), $1 \mu \mathrm{g} / \mathrm{ml}$ aprotinin, leupeptin, and pepstatin, and $2 \mathrm{mM} \mathrm{Na}_{3} \mathrm{VO}_{4}$ ] at room temperature for $2 \mathrm{~h}$ with gentle rotation. Samples were centrifuged $(15,000 \mathrm{x} \mathrm{g})$ for $3 \mathrm{~min}$ and washed three times with binding buffer at $4^{\circ} \mathrm{C}$. After washing, $25 \mu \mathrm{l}$ of $2 \mathrm{X}$ sample buffer was added and boiled for $5 \mathrm{~min}$. The result was analyzed by SDS-PAGE and immunoblotting using anti-p65 NF-кB antibody (Santa Cruz).

\section{Results}

Inhibition of GSK-3ß with $\mathrm{LiCl}$ enhances reovirus-induced cell death. To begin testing whether the elevated expression of $\beta$-catenin noted in colon cancer cells might enhance the replication of reovirus, we treated $\mathrm{HEK} 293$ cells with $\mathrm{LiCl}$ (a known GSK-3ß inhibitor) for $24 \mathrm{~h}$ to achieve up-regulation of $\beta$-catenin. As expected, $\mathrm{LiCl}$ induced elevated expression of $\beta$-catenin as revealed by immunoblotting (Fig. 1A) in a dose-dependent manner. The level of $B$-catenin was maximized (up to 10 -fold) at $20 \mathrm{mM}$ of $\mathrm{LiCl}$, and since we observed a significant inhibition of cell proliferation at $30 \mathrm{mM}$ of $\mathrm{LiCl}$ (data not shown), we used $20 \mathrm{mM}$ of $\mathrm{LiCl}$ thereafter. Live HEK293 cells treated with $\mathrm{LiCl}$, reovirus alone, or reovirus and $\mathrm{LiCl}$ were counted at $36 \mathrm{~h}$ post-treatment using trypan 
A
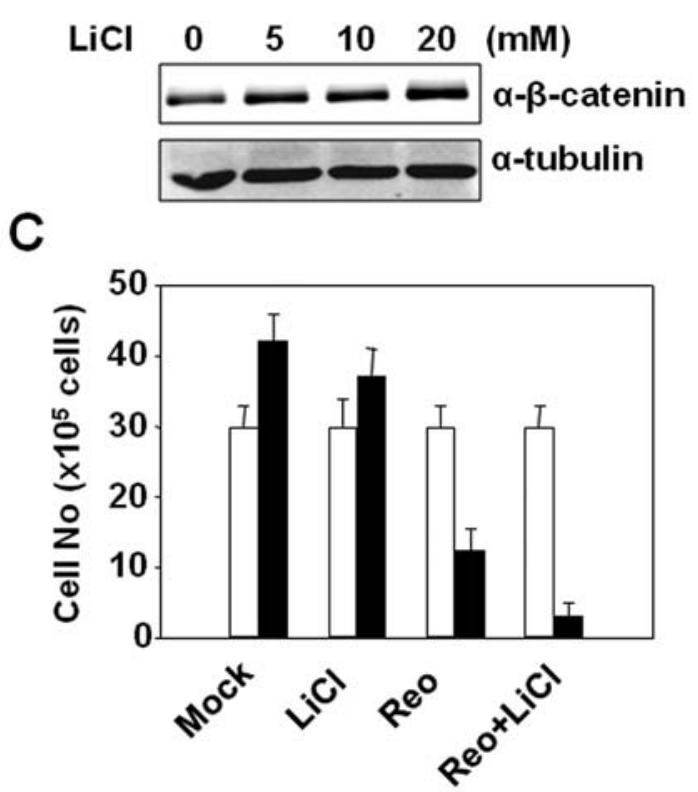

blue exclusion. As noted in Fig. 1B, LiCl treatment alone slightly inhibited cell proliferation to a certain extent compared to mock treatment. Infection of HEK293 cells with reovirus $(\mathrm{MOI}=1)$ caused partial cell lysis at $36 \mathrm{~h}$ post-infection (Fig. 1B). However, co-treatment with $\mathrm{LiCl}$ and reovirus efficiently destroyed HEK293 cells compared to infection of HEK293 cells with reovirus alone (Fig. 1B and C). Only 10\% of HEK293 cells survived at $36 \mathrm{~h}$ after co-treatment with reovirus and $\mathrm{LiCl}$, whereas $35 \%$ of HEK293 cells survived $36 \mathrm{~h}$ after treatment with reovirus alone, consistent with the speculation that up-regulation of $\beta$-catenin by inhibition of GSK-3ß promotes reovirus-induced cell death.

Enhancement of reovirus-induced cell death by $\mathrm{LiCl}$ is not linked to reovirus propagation. If this is true, then elevated expression of $\beta$-catenin in the presence of $\mathrm{LiCl}$ might be predicted to enhance reoviral replication and consequently reovirus-induced cell death. We therefore tested this possibility by determining reoviral protein levels in cells treated with reovirus or reovirus and $\mathrm{LiCl}$ using polyclonal anti-reovirus antibodies. However, the levels of reoviral protein detected in cell lysates treated with reovirus alone were actually greater than those in the cell lysates co-treated with reovirus and $\mathrm{LiCl}$ (Fig. 2). Thus, elevated reovirus replication is not likely a direct cause of enhanced cell death in the cells treated with reovirus and $\mathrm{LiCl}$. The up-regulation of $\beta$-catenin by the inhibition of GSK-3ß is not linked to reovirus replication in this experimental model.

Elevated expression of $\beta$-catenin by Wht signaling does not confer preferential replication of reovirus. To further show that enhanced $\beta$-catenin does not increase the replication of reovirus, we employed HEK293 cells expressing human Frizzled-1 (HEK293-Fz) as a receptor of Wnt-3a. HEK293-Fz cells were cultured in Wnt3a-conditioned medium (CM) for the indicated time intervals and amounts (Fig. 3A and B), resulting in maximal induction of $\beta$-catenin by 5 -fold. Under
B

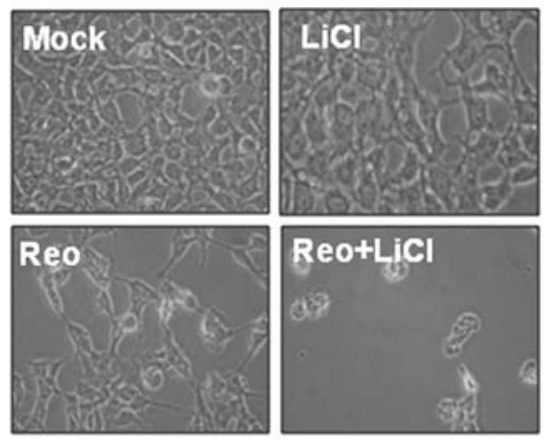

Figure 1. GSK-3ß inhibition enhances reovirus-induced cell death. (A) HEK293 cells were treated with $\mathrm{LiCl}$ at 5,10 or $20 \mathrm{mM}$ and harvested at $24 \mathrm{~h}$ post-treatment. Expression of $\beta$-catenin was examined by immunoblotting with anti-ß-catenin antibody. (B and C) HEK293 cells were treated with $\mathrm{LiCl}(20 \mathrm{mM})$, reovirus $(\mathrm{Reo})(\mathrm{MOI}=1)$ alone, or reovirus $(\mathrm{MOI}=1)$ and $\mathrm{LiCl}(20 \mathrm{mM})$, and the cells were photographed (x200) and counted using trypan blue after $36 \mathrm{~h}$. White bars indicate the cell number of inoculation at $0 \mathrm{~h}$ while black bars indicate the cell number treated with indicated agents at $36 \mathrm{~h}$ post-treatment.

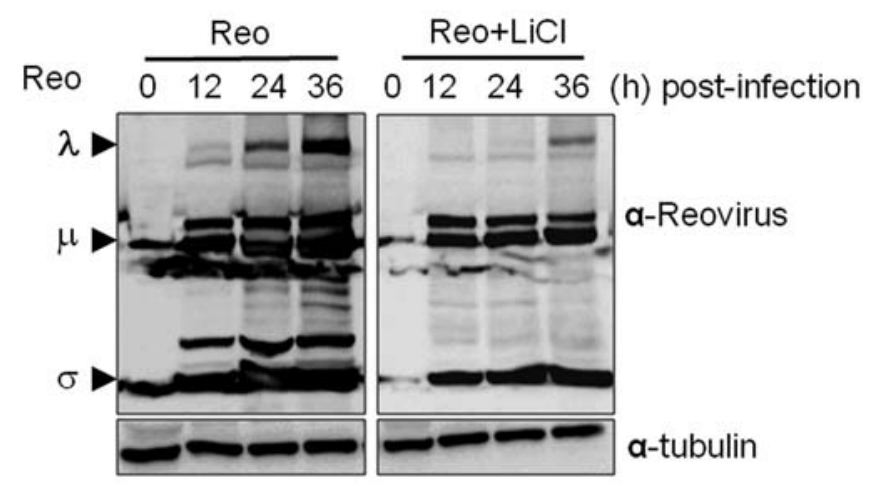

Figure 2. Enhancement of reovirus-induced cell death under $\mathrm{LiCl}$ is not linked to elevated reoviral protein synthesis. HEK293 cells were treated with reovirus $(\mathrm{Reo})(\mathrm{MOI}=1)$ or reovirus $(\mathrm{MOI}=1)$ and $\mathrm{LiCl}(20 \mathrm{mM})$ and harvested at 12, 24 and $36 \mathrm{~h}$ post-infection. Reoviral replication was determined by measuring protein levels using polyclonal antibodies against the reovirus. Polyclonal anti-reovirus antibodies were used for the detection of $\lambda, \mu$ and $\sigma$ reoviral proteins.

conditions of continual Wnt3a signaling and $\beta$-catenin induction, HEK293-Fz cells were infected with reovirus, and reoviral protein levels were analyzed with immunoblotting over 36 h. As shown in Fig. 3C, reoviral protein levels from HEK293-Fz cells treated with Wnt3a-CM were similar to those from HEK293-Fz treated with control-CM. This result further demonstrated that the elevated expression of $B$ catenin by Wnt-3a signaling did not enhance reovirus replication in the HEK293-Fz cells.

Inhibition of $G S K-3 \beta$ suppresses reovirus-induced $N F-\kappa B$ activity, leading to the promotion of reovirus-induced apoptosis. First, we attempted to confirm that $\mathrm{LiCl}$ treatment inhibits GSK-3ß activity as described elsewhere (28) using an anti-phospho-GSK-3ß (Ser9) antibody. As shown in Fig. 4A, LiCl treatment enhanced GSK-3ß phosphorylation, 
A

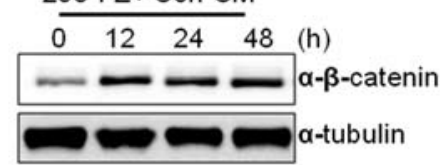

B 293-FZ+Wnt3a-CM

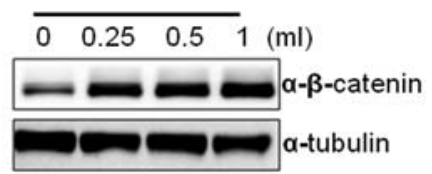

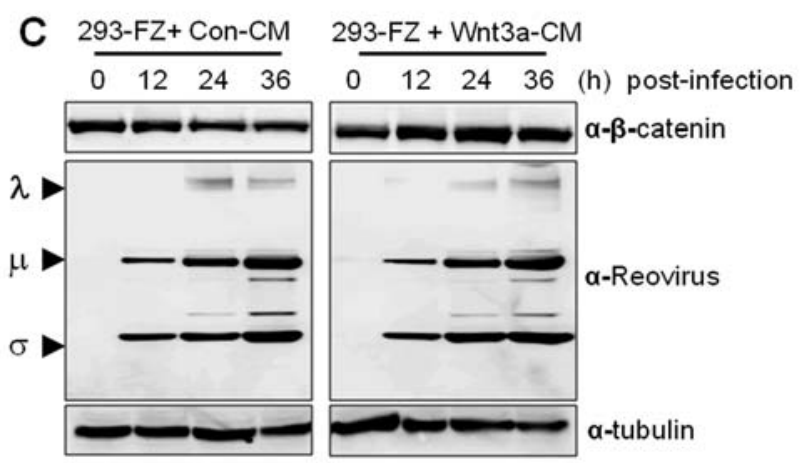

Figure 3. The enhanced level of ß-catenin by Wnt3a does not confer a preferential replication of reovirus. (A and B) HEK293-Fz (293-FZ) cells were treated with Wnt3a-conditioned medium (CM) for 12,24 and $48 \mathrm{~h}$ or with different amounts $(0.25,0.5$ and $1 \mathrm{ml})$ for $24 \mathrm{~h}$ and harvested for the measurement of the B-catenin level. (C) HEK293-Fz cells were treated with reovirus in the presence of control conditioned medium (Con-CM) or reovirus in the presence of conditioned medium containing Wnt3a (Wnt3a-CM; $0.5 \mathrm{ml}$ ) and harvested at 12, 24, and $36 \mathrm{~h}$ post-treatment. The increased level of $\beta$-catenin in the presence of Wnt3a-CM was examined with anti-ß-catenin antibody. Reoviral replication was examined by protein level of reovirus using polyclonal antibody.

A

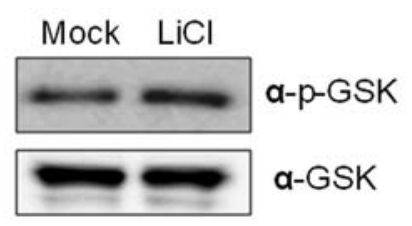

B
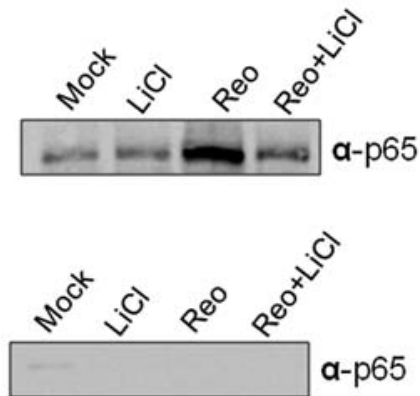

Pre-treatment; anti-p65 Ab

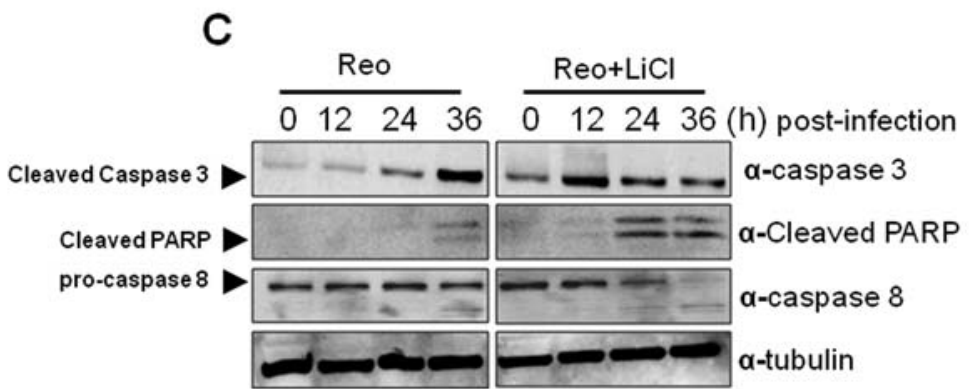

Figure 4. Inhibition of GSK-3ß promotes reovirus-induced apoptosis by inhibition of NF-kB. (A) HEK293 cells were treated with LiCl (20 mM) for 24 h and harvested for the detection of phosphorylation of GSK-3ß (Ser9). Phosphorylated GSK-3ß was examined with anti-phospho-GSK-3ß (Ser9) antibody. (B) HEK293 cells were treated with $\mathrm{LiCl}(20 \mathrm{mM})$, reovirus $(\mathrm{Reo})(\mathrm{MOI}=1)$, or reovirus $(\mathrm{MOI}=1)$ and $\mathrm{LiCl}(20 \mathrm{mM})$, and the nuclear extracts from the samples were prepared after $12 \mathrm{~h}$. NF- $\mathrm{kB}$ target oligonucleotides conjugated with agarose $(100 \mu \mathrm{g})$ were added to the nuclear extracts, and the protein bound to the oligonucleotides was harvested and confirmed by immunoblotting using anti-p65 antibody since p65 is a subunit of the NF-kB complex. To confirm specific binding between the NF-kB oligonucleotide and p65, p65 antibody was added to the nuclear extract followed by treatment with Protein A/G to remove p65 protein. (C) HEK293 cells were treated with reovirus (MOI=1) alone or reovirus (MOI=1) and $\mathrm{LiCl}(20 \mathrm{mM})$ and harvested at 12,24 and $36 \mathrm{~h}$ posttreatment. Protein levels of pro-caspase 8, cleaved caspase 3, and cleaved PARP were examined by immunoblotting with anti-caspase 8, 3 and anti-PARP antibodies, respectively.

indicating that $\mathrm{LiCl}$ treatment reduces GSK-3ß activity, leading to up-regulation of $B$-catenin. We therefore wished to test other possible roles of GSK inhibition in the enhance- ment of reovirus-induced cell death. A role for GSK-3ß in $\mathrm{NF}-\kappa \mathrm{B}$ activation has previously been reported $(23,29)$, and we therefore wondered whether NF- $\mathrm{B}$ modulation mediated 
A

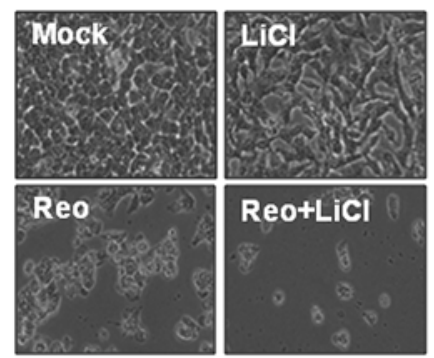

C

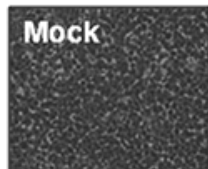

Reo

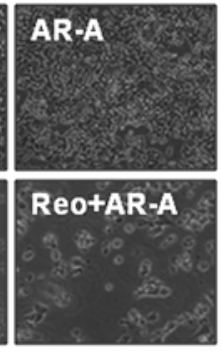

B
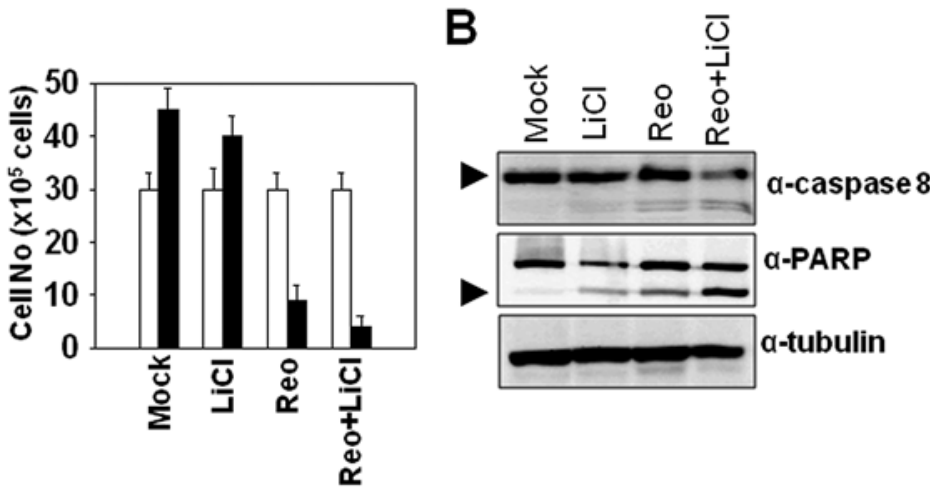

D
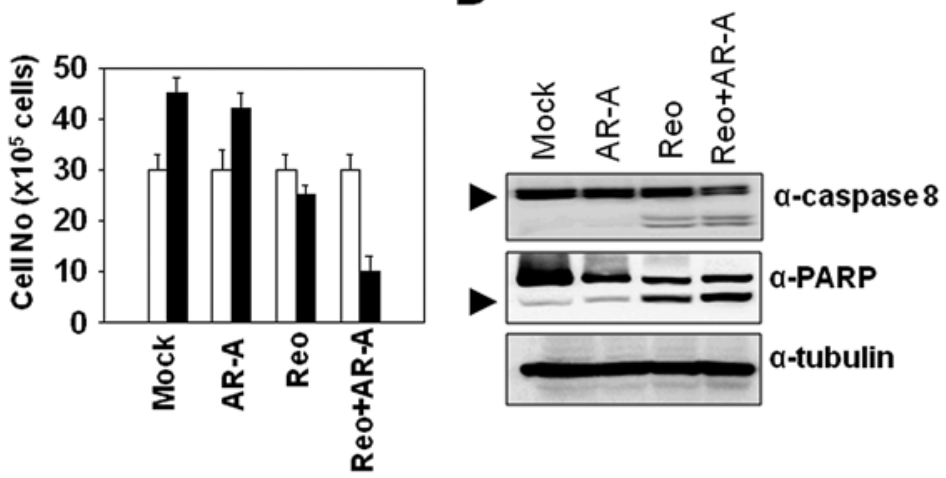

Figure 5. GSK-3ß inhibition accelerates reovirus-induced apoptosis in colon cancer HCT116 cells. (A and B) HCT116 cells were treated with LiCl (20 mM), reovirus $(\mathrm{Reo})(\mathrm{MOI}=1)$, or reovirus $(\mathrm{MOI}=1)$ and $\mathrm{LiCl}(20 \mathrm{mM})$, and the cell viability was recorded under the microscope $(\mathrm{x} 200)$ at $36 \mathrm{~h}$ post-treatment. The cells were counted using trypan blue after $36 \mathrm{~h}$. White bars indicate the cell number of inoculation at $0 \mathrm{~h}$ while black bars indicate the cell number treated with indicated agents at $36 \mathrm{~h}$ post-treatment. The cells were harvested at $36 \mathrm{~h}$ post-treatment, and cell lysates were separated on 10\% SDS-PAGE for immunoblotting with anti-caspase 8 antibody and anti-PARP antibody. Arrowheads indicate pro-caspase 8 and cleaved PARP, respectively. (C and D) HCT116 cells were treated with AR-A014418 (AR-A; $10 \mu \mathrm{M})$, reovirus $(\mathrm{MOI}=1)$, or reovirus $(\mathrm{MOI}=1)$ and AR-A014418 (10 $\mu \mathrm{M})$, and cells were photographed, counted, and proteins were analyzed as described in $\mathrm{A}$ and $\mathrm{B}$.

by GSK inhibition might promote reovirus-induced cell death. After we prepared nuclear extracts from HEK293 cells treated with reovirus alone or reovirus and $\mathrm{LiCl}$, we analyzed the binding ability of p65 (the major subunit of the NF- $\mathrm{B}$ dimer) to NF-кB oligonucleotide target. As shown in Fig. 4B, treatment with reovirus strongly induced the binding ability of p65 protein to the NF- $\mathrm{KB}$ oligonucleotide at $12 \mathrm{~h}$ postinfection. However, co-administration of reovirus with $\mathrm{LiCl}$ prevented the enhanced binding of p65 to the NF-кB oligonucleotide. As a control, we added anti-p65 antibody to the nuclear extract fraction, and then removed p65 in the nuclear extract with protein $\mathrm{A} / \mathrm{G}$-conjugated agarose, preventing binding to the NF- $\mathrm{KB}$ oligonucleotide (Fig. 4B). Our result suggests that GSK-3B positively regulates reovirus-induced $\mathrm{NF}-\kappa \mathrm{B}$ activation and that $\mathrm{LiCl}$ can block this activation.

Furthermore, to examine the consequences of NF- $\mathrm{KB}$ blockade by inhibition of GSK-3ß, we investigated apoptosis in the cells treated with reovirus alone or reovirus and $\mathrm{LiCl}$. Treatment with $\mathrm{LiCl}$ alone did not induce apoptosis in HEK293 cells, whereas cells treated with reovirus alone showed activation of caspase 3 and partial cleavage of PARP (a caspase 3 substrate) and caspase 8 by 36 h. In contrast, HEK293 cells treated with reovirus and $\mathrm{LiCl}$ exhibited a clear acceleration of apoptotic events with extensive cleavage of PARP by $12 \mathrm{~h}$ and activation of caspase 3 and caspase 8 at
$24 \mathrm{~h}$ post-infection (Fig. 4C). The results suggest that GSK$3 \beta$ inhibition by $\mathrm{LiCl}$ accelerates the kinetics of reovirusinduced apoptosis of the cell.

GSK-3ß inhibition enhances reovirus-induced apoptosis of colon cancer cells. As we observed that GSK-3ß inhibition by $\mathrm{LiCl}$ enhances reovirus-induced apoptosis in HEK293 cells (Figs. 1 and 4), we wondered whether this effect of GSK-3B inhibition might also be detected in colon cancer cells. To address this issue, we employed the HCT116 colon cancer cell line which shows an up-regulated level of B-catenin due to a mutated $\beta$-catenin gene. When HCT116 cells were treated with $\mathrm{LiCl}$ alone, cell proliferation was very slightly inhibited compared to mock treatment (Fig. 5A). When the cells were treated with reovirus and $\mathrm{LiCl}$, cell viability was significantly decreased compared to that of cells treated with reovirus (Fig. 5A). Only 15\% of HCT116 cells survived at $36 \mathrm{~h}$ after co-treatment with reovirus and $\mathrm{LiCl}$, whereas $\sim 35 \%$ of HCT116 cells survived $36 \mathrm{~h}$ after treatment with reovirus alone (Fig. 5A). We also tested a small molecule GSK-3ß inhibitor AR-A014418 and found that treatment with this agent enhanced reovirus-induced cell death similarly to $\mathrm{LiCl}$ treatment (Fig. 5C). The reovirus-induced cell death in both cases was attributed to apoptosis through caspase 8 cascades in the HCT116 cells (Fig. 5B and D). These results suggest that co-treatment with reovirus and GSK inhibitors 

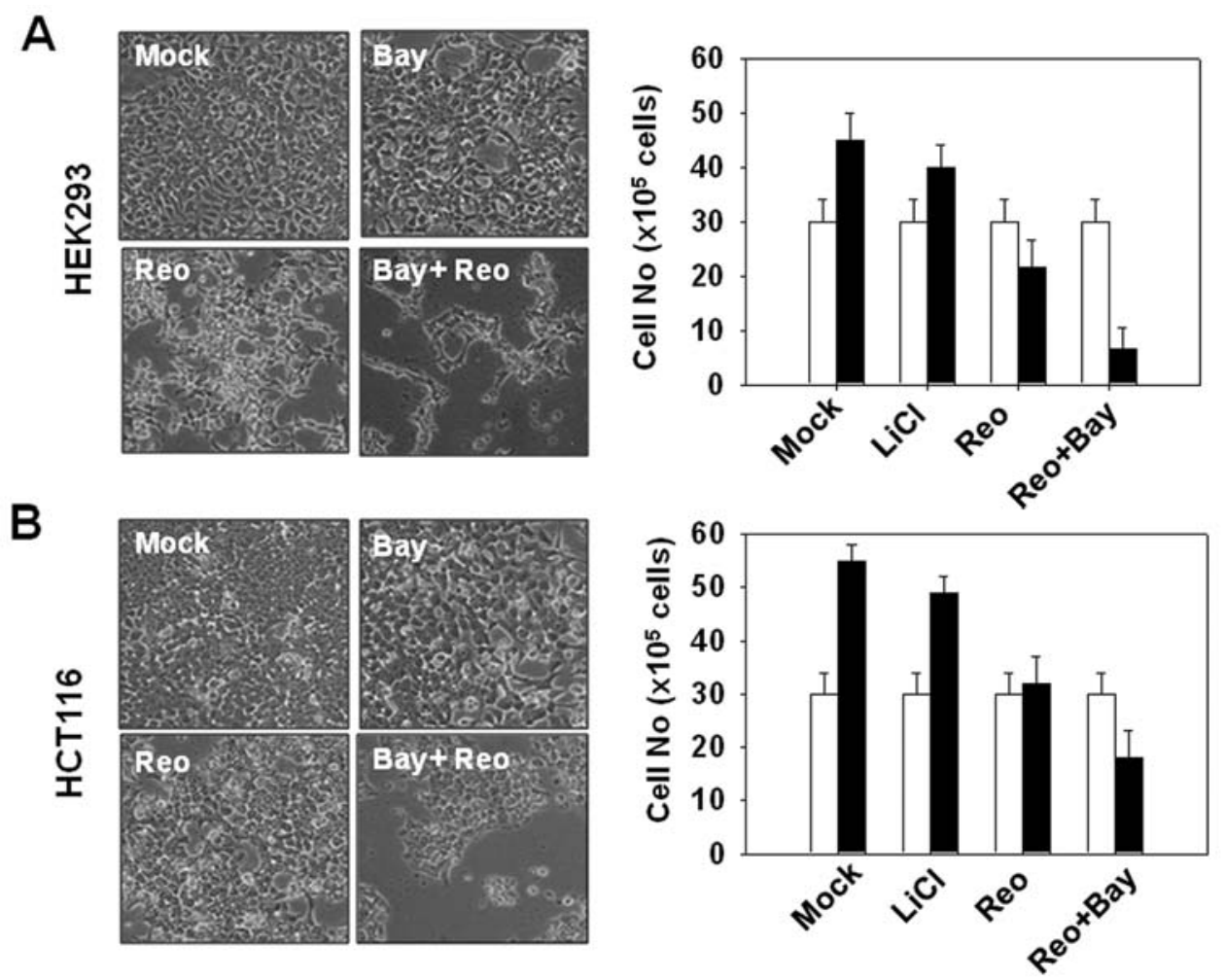

Figure 6. NF-kB inhibition promotes reovirus-induced apoptosis of HEK 293 cells or HCT colon cancer cells. (A and B) HEK293 and HCT116 cells were treated with Bay 11-7082 (Bay; $10 \mu \mathrm{M})$, reovirus (Reo) $(\mathrm{MOI}=1)$, or reovirus $(\mathrm{MOI}=1)$ and Bay 11-7082 $(10 \mu \mathrm{M})$, and the cell viability was recorded under the microscope $(\mathrm{x} 200)$ at 24 and $48 \mathrm{~h}$ post-treatment, respectively. The cells were counted using trypan blue at 24 or $48 \mathrm{~h}$ post-treatment. White bars indicate the cell number of inoculation at $0 \mathrm{~h}$ while black bars indicate the cell number treated with indicated agents at 24 or $48 \mathrm{~h}$ post-treatment.

may efficiently kill colon cancer cells more rapidly and to a greater extent than with reovirus alone.

Inhibition of $N F-\kappa B$ sensitizes apoptosis of HEK293 or HCT116 cells during reovirus infection. To prove whether inhibition of NF- $\mathrm{BB}$ enhances reovirus-mediated apoptosis in HEK293 and HCT116 cells, we treated the cells with Bay 11-7082 during reovirus infection. As shown in Fig. 6A, Bay 11-7082 treatment $(10 \mu \mathrm{M})$ slightly inhibited cell proliferation in HEK 293 cells compared to mock treatment. When the cells were treated with reovirus and Bay 11-7082, cell viability was significantly decreased compared to that of cells treated with reovirus alone. Only $10 \%$ of HEK293 cells survived at $24 \mathrm{~h}$ after co-treatment with reovirus and Bay 11-7082, whereas $45 \%$ of HEK293 cells survived after treatment with reovirus infection alone (Fig. 6A). We also observed that the NF-кB inhibitor enhanced reovirus-mediated apoptosis of HCT116 cells as seen in HEK293 cells. Co-treatment with this NF-кB inhibitor and reovirus induced up to approximately $80 \%$ cell death at $48 \mathrm{~h}$ post-treatment while reovirus infection alone induced $45 \%$ cell death at $48 \mathrm{~h}$ post-treatment (Fig. 6B). Accordingly, the results suggest that inhibition of $\mathrm{NF}-\kappa \mathrm{B}$ sensitizes apoptosis of HEK293 cells or HCT116 colon cancer cells during reovirus infection.

\section{Discussion}

Colorectal cancer is the third most common cancer diagnosed in the US and is increasing in incidence as well in Asian countries (30). Mutations not only in the K-ras proto-oncogene but also in components of the $\mathrm{Wnt} / \mathrm{B}$-catenin signaling pathway are frequently detected in colorectal cancers (31). Although Ras signaling plays a critical role in dictating host cell permissiveness to reovirus (6), other signaling pathways may also contribute susceptibility to reoviral replication and oncolysis (9). Since it has been reported that reovirus efficiently kills many colon cancer cell lines (12) in vitro and in a rodent model in vivo $(12,14,25)$, we wondered whether upregulation of $\beta$-catenin might in some way enhance reovirus replication. However, we found that overexpression of $\beta$ catenin as induced by exposure to the GSK-3ß inhibitor $\mathrm{LiCl}$, did not enhance reoviral replication in HEK293 and HCT116 cells. Thus, at present it appears that $\beta$-catenin does not play a role similar to that of the activated Ras oncoprotein to facilitate reovirus replication in the cell. Consistent with our results, treatment of pancreatic cancer cells with GSK-3ß inhibitor also decreases cell survival and proliferation (29).

GSK-3ß is active in resting cells, leading to the constitutive degradation of $\beta$-catenin via ubiquitin-proteosomes (21). During Wnt/ß-catenin or PI-3 kinase signaling, GSK-3ß becomes phosphorylated and inactivated, and subsequently $\beta$-catenin is up-regulated $(32,33)$. Considering that inhibition of GSK-3ß results in the up-regulation of various proto-oncoproteins such as $B$-catenin, cyclin-D1, and $\mathrm{c}-\mathrm{Myc}$, the inhibition of GSK-3ß may increase the risk of carcinogenesis (34). On the other hand, GSK-3ß-knockout MEFs have been used to show that GSK-3ß participates in cell survival and proliferation (23), and GSK-3ß inhibition also suppressed the 
development of cancer in a xenograft of a tumor model (35).

Consistent with this, GSK-3ß also provides a pro-survival signal in a Wnt3/ß-catenin-independent manner $(36,37)$. GSK-3ß physically interacts with and activates MEKK1, leading to stimulation of JNK, p42/p44 MAPK, and NF-кB pathways (36). In addition, GSK-3ß depletion abolishes the TNF-induced phosphorylation of $\mathrm{p} 65$, a subunit of the NF-kB complex (37). Herein, a role for GSK-3ß as a pro-survival signal molecule is consistent with our results showing the reduction of reovirus-induced $\mathrm{NF}-\kappa \mathrm{B}$ activation and the enhancement of reovirus-induced apoptosis through GSK-3ß inhibition by $\mathrm{LiCl}$ or the small molecule inhibitor ARA014418 (Figs. 4 and 5). Furthermore, we demonstrated that inhibition of $\mathrm{NF}-\kappa \mathrm{B}$ enhances reovirus-mediated cell death in HEK 293 cells or HCT116 colon cancer cells during reovirus infection, confirming that blockage of NF$\kappa \mathrm{B}$ with the GSK-3ß inhibitor promotes reovirus-induced apoptosis (Figs. 4 and 5). Therefore, inhibitors of GSK-3B may have therapeutic potential in cancers and inflammation as mediated by NF- $\mathrm{NB}$.

Taken together, our results raise the possibility that combined treatment with reovirus and GSK-3ß inhibitors may provide an enhanced therapeutic approach for the treatment of colon cancer compared to reovirus treatment alone.

\section{Acknowledgements}

This work was supported by the Korean Research Foundation Grant funded by the Korean Government (KRF-2008-313E00113) to Y-H.C. This work was supported by the Korea Institute of Science and Technology Evaluation and Planning (KISTEP) and by the Ministry of Science and Technology (MOST), Korean government, through its National Nuclear Technology Program (S.O). This study was also supported by a grant of the Korean Health 21 R\&D Project, Ministry of Health and Welfare, Korea (00-PJ3-PG6-GN07-001) (B.H.J).

\section{References}

1. Norman KL, Hirasawa K, Yang AD, Shields MA and Lee PW: Reovirus oncolysis: the Ras/RalGEF/p38 pathway dictates host cell permissiveness to reovirus infection. Proc Natl Acad Sci USA 101: 11099-11104, 2004.

2. Rosen L, Evans HE and Spickard A: Reovirus infections in human volunteers. Am J Hyg 77: 29-37, 1963.

3. Kim M, Chung YH and Johnston RN: Reovirus and tumor oncolysis. J Microbiol 45: 187-192, 2007.

4. Duncan MR, Stanish SM and Cox DC: Differential sensitivity of normal and transformed human cells to reovirus infection. J Virol 28: 444-449, 1978.

5. Hashiro G, Loh PC and Yau JT: The preferential cytotoxicity of reovirus for certain transformed cell lines. Arch Virol 54: 307-315, 1977

6. Coffey MC, Strong JE, Forsyth PA and Lee PW: Reovirus therapy of tumors with activated Ras pathway. Science 282: 1332-1334, 1998.

7. Strong JE, Coffey MC, Tang D, Sabinin P and Lee PW: The molecular basis of viral oncolysis: usurpation of the Ras signaling pathway by reovirus. EMBO J 17: 3351-3362, 1998.

8. Hirasawa K, Nishikawa SG, Norman KL, Coffey MC, Thompson BG, Yoon CS, Waisman DM and Lee PW: Systemic reovirus therapy of metastatic cancer in immune-competent mice. Cancer Res 63: 348-353, 2003.
9. Park EH, Koh SS, Srisuttee R, Cho IR, Min HJ, Jhun BH, Lee YS, Jang KL, Kim CH, Johnston RN and Chung YH: Expression of $\mathrm{HBX}$, an oncoprotein of hepatitis B virus, blocks reoviral oncolysis of hepatocellular carcinoma cells. Cancer Gene Ther (In press).

10. Yang WQ, Lun X, Palmer CA, Wilcox ME, Muzik H, Shi ZQ, Dyck R, Coffey M, Thompson B, Hamilton M, Nishikawa SG, Brasher PM, Fonseca K, George D, Rewcastle NB, Johnston RN, Stewart D, Lee PW, Senger DL and Forsyth PA: Efficacy and safety evaluation of human reovirus type 3 in immunocompetent animals: racine and nonhuman primates. Clin Cancer Res 10: 8561-8576, 2004.

11. Norman KL and Lee PW: Not all viruses are bad guys: the case for reovirus in cancer therapy. Drug Discov Today 10: 847-855, 2005.

12. Hirasawa K, Nishikawa SG, Norman KL, Alain T, Kossakowska A and Lee PW: Oncolytic reovirus against ovarian and colon cancer. Cancer Res 62: 1696-1701, 2002.

13. Ikeda Y, Nishimura G, Yanoma S, Kubota A, Furukawa M and Tsukuda M: Reovirus oncolysis in human head and neck squamous carcinoma cells. Auris Nasus Larynx 31: 407-412, 2004.

14. Alain T, Wong JF, Endersby R, Urbanski SJ, Lee PW, Muruve DA, Johnston RN, Forsyth PA and Beck PL: Reovirus decreases azoxymethane-induced aberrant crypt foci and colon cancer in a rodent model. Cancer Gene Ther 14: 867-872, 2007.

15. Clarke P, Meintzer SM, Gibson S, Widmann C, Garrington TP Johnson GL and Tyler KL: Reovirus-induced apoptosis is mediated by TRAIL. J Virol 74: 8135-8139, 2000.

16. Clarke P, Meintzer SM, Widmann C, Johnson GL and Tyler KL: Reovirus infection activates JNK and the JNK-dependent transcription factor c-Jun. J Virol 75: 11275-11283, 2001.

17. Clarke P, Meintzer SM, Spalding AC, Johnson GL and Tyler KL: Caspase 8-dependent sensitization of cancer cells to TRAILinduced apoptosis following reovirus-infection. Oncogene 20: 6910-6919, 2001.

18. Frame S and Cohen P: GSK3 takes centre stage more than 20 years after its discovery. Biochem J 359: 1-16, 2001.

19. Woodgett JR: Molecular cloning and expression of glycogen synthase kinase-3/factor A. EMBO J 9: 2431-2438, 1990.

20. Doble BW and Woodgett JR: GSK-3: tricks of the trade for a multi-tasking kinase. J Cell Sci 116: 1175-1186, 2003.

21. Aberle H, Bauer A, Stappert J, Kispert A and Kemler R: Betacatenin is a target for the ubiquitin-proteasome pathway. EMBO J 16: 3797-3804, 1997.

22. Shakoori A, Ougolkov A, Yu ZW, Zhang B, Modarressi MH, Billadeau DD, Mai M, Takahashi $Y$ and Minamoto T: Deregulated GSK3beta activity in colorectal cancer: its association with tumor cell survival and proliferation. Biochem Biophys Res Commun 334: 1365-1373, 2005.

23. Hoeflich KP, Luo J, Rubie EA, Tsao MS, Jin O and Woodgett JR: Requirement for glycogen synthase kinase-3beta in cell survival and NF-kappaB activation. Nature 406: 86-90, 2000.

24. Alain T, Hirasawa K, Pon KJ, Nishikawa SG, Urbanski SJ, Auer Y, Luider J, Martin A, Johnston RN, JanowskaWieczorek A, Lee PW and Kossakowska AE: Reovirus therapy of lymphoid malignancies. Blood 100: 4146-4153, 2002.

25. Kim M, Egan C, Alain T, Urbanski SJ, Lee PW, Forsyth PA and Johnston RN: Acquired resistance to reoviral oncolysis in Rastransformed fibrosarcoma cells. Oncogene 26: 4124-4134, 2007.

26. Dignam JD, Lebovitz RM and Roeder RG: Accurate transcription initiation by RNA polymerase II in a soluble extract from isolated mammalian nuclei. Nucleic Acids Res 11: 1475-1489, 1983.

27. Ardeshna KM, Pizzey AR, Devereux S and Khwaja A: The PI3 kinase, p38 SAP kinase, and NF-kappaB signal transduction pathways are involved in the survival and maturation of lipopolysaccharide-stimulated human monocyte-derived dendritic cells. Blood 96: 1039-1046, 2000.

28. Klein PS and Melton DA: A molecular mechanism for the effect of lithium on development. Proc Natl Acad Sci USA 93: 8455-8459, 1996.

29. Ougolkov AV, Fernandez-Zapico ME, Savoy DN, Urrutia RA and Billadeau DD: Glycogen synthase kinase-3beta participates in nuclear factor kappaB-mediated gene transcription and cell survival in pancreatic cancer cells. Cancer Res 65: 2076-2081, 2005 . 
30. Sung J: Colorectal cancer screening: its time for action in Asia. Cancer Detect Prev 31: 1-2, 2007.

31. Takayama T, Ohi M, Hayashi T, Miyanishi K, Nobuoka A, Nakajima T, Satoh T, Takimoto R, Kato J, Sakamaki S and Niitsu Y: Analysis of K-ras, APC, and beta-catenin in aberrant crypt foci in sporadic adenoma, cancer, and familial adenomatous polyposis. Gastroenterology 121: 599-611, 2001.

32. Cohen P and Frame S: The renaissance of GSK3. Nat Rev Mol Cell Biol 2: 769-776, 2001

33. Nelson WJ and Nusse R: Convergence of Wnt, beta-catenin, and cadherin pathways. Science 303: 1483-1487, 2004.

34. Cohen P and Goedert M: GSK3 inhibitors: development and therapeutic potential. Nat Rev Drug Discov 3: 479-487, 2004.

35. Shakoori A, Mai W, Miyashita K, Yasumoto K, Takahashi Y, Ooi A, Kawakami K and Minamoto T: Inhibition of GSK-3 beta activity attenuates proliferation of human colon cancer cells in rodents. Cancer Sci 98: 1388-1393, 2007.
36. Kim JW, Lee JE, Kim MJ, Cho EG, Cho SG and Choi EJ: Glycogen synthase kinase 3 beta is a natural activator of mitogenactivated protein kinase/extracellular signal-regulated kinase kinase kinase 1 (MEKK1). J Biol Chem 278: 13995-14001, 2003.

37. Takada Y, Fang X, Jamaluddin MS, Boyd DD and Aggarwal BB Genetic deletion of glycogen synthase kinase-3beta abrogates activation of IkappaBalpha kinase, JNK, Akt, and p44/p42 MAPK but potentiates apoptosis induced by tumor necrosis factor. J Biol Chem 279: 39541-39554, 2004. 